\title{
Protective effect of the polyherbal formulation, Nalpamaram against ethanol induced hepatotoxicity in rats
}

\author{
S. Jyothilekshmi, A. K. Valsa and Ramadasan Kuttan* \\ Postgraduate and Research Department of Microbiology, Sree Sankara College, Kalady-683574, Kerala, India. \\ *Amala Cancer Research Centre, Amala Nagar, Thrissur-680555, Kerala, India
}

\section{Article Info \\ Article history \\ Received 2 August 2020 \\ Revised 22 September 2020 \\ Accepted 25 September 2020 \\ Published online 30 December 2020}

\section{Keywords}

Ethanol toxicity

Hepatoprotective action

Nalpamaram

Polyherbal formulation

Silymarin

\begin{abstract}
Nalpamaram which constitutes a group of four plants, Ficus racemosa, Ficus microcarpa, Ficus benghalensis and Ficus religiosa is one of the polyherbal formulations, used by ayurvedic practitioners for the treatment of a variety of health problems. In the present study, the hepatoprotective activity of aqueous extract of the barks of Nalpamaram (NMAE) against ethanol induced hepatotoxicity was studied in male albino rats. The levels of the toxicity marker enzymes aspartate transaminase (AST), alanine transaminase (ALT), alkaline phosphatase (ALP), gamma glutamyl transferase (GGT), and bilirubin showed a significant increase in the ethanol treated group indicating liver injury. On treatment with NMAE at various concentrations, the activity of the enzymes AST, ALT, ALP and GGT, and total bilirubin significantly decreased compared to the ethanol treated group. The total protein and albumin levels increased on treatment with NMAE. The hepatoprotective activity was also supported by the histopathological studies of the liver tissue. The effects of NMAE at a dose of $500 \mathrm{mg} / \mathrm{kg} \mathrm{b}$.wt/day were comparable to that of the standard drug silymarin.
\end{abstract}

\section{Introduction}

Liver is one of the most important tissues of the human body and is the primary site of metabolism, detoxification and secretion. Liver plays a major role in physiological homeostasis. It is also the site of the biochemical pathways involved in growth, immunity, the supply of nutrients and energy production (Ahsan et al., 2009). Liver diseases have become a worldwide health problem that accounts for a very high death rate. Hepatic damage may be caused by excess ethanol consumption, the use of high doses of paracetamol, antibiotics, environmental pollutants and microbial infection (Daniyal et al., 2019). Ethanol damages the liver by accumulating fat, inflammation and oxidative stress which may progress to fibrosis and cirrhosis (Osna et al., 2017). In recent years, plant extracts have received attention as hepatoprotective agents as the available hepatoprotective drugs often fail to restore liver functions (Kumar and Pari, 2003). In the traditional Indian system of medicine, plant extracts are used to treat a variety of diseases, including those of liver (Chattopadhyay, 2003; Gaurav et al., 2017). In the Ayurvedic system, combinations of plant extracts are considered to have greater therapeutic efficacy than individual extracts. Polyherbal formulations (PHF) may produce better results by acting at multiple targets at a time or one herb may nullify the deleterious side effects of the others (Parasuraman et al., 2014).

Corresponding author: Dr. A. K. Valsa Associate Professor, Postgraduate and Research Department of Microbiology, Sree Sankara College, Kalady-683574, Kerala, India E-mail: valsaak@yahoo.com

Tel.: +91-9846394748

Copyright (c) 2020 Ukaaz Publications. All rights reserved.

Email: ukaaz@yahoo.com; Website: www.ukaazpublications.com
Nalpamaram is one of the polyherbal formulations used by Ayurvedic practitioners for the treatment of a variety of health problems. The four trees that constitute Nalpamaram are Ficus racemosa (FR), Ficus microcarpa (FM), Ficus benghalensis (FB) and Ficus religiosa (FG). In vernacular, they are called Athi, Ithi, Peral and Arayal, respectively. They belong to family Moraceae. The aqueous extracts of the barks of FR, FM, FB and FG form an ingredient in many of the Ayurvedic medicines. Nalpamaram is credited with cooling, soothing, antiinflammatory and antipruritic properties and is used in the treatment of various diseases to relieve burning sensation, haemoptysis, wounds and ulcers (Chopra et al., 1992; Warrier et al., 1995). The leaves and bark of FR and FG are reported to have hepatoprotective and nephroprotective activities (Mandal et al., 1999; Channabasavaraj et al., 2008).

Nalpamaram which is a concoction of FR, FM, FB and FG may exhibit hepatoprotective action. However, a detailed scientific study is found to be essential to explore its hepatoprotective action. Hence, the present study focuses on the hepatoprotective activity of the aqueous extract of Nalpamaram on ethanol induced hepatotoxicity in male albino rats.

\section{Materials and Methods}

\subsection{Preparation of the extract}

The preparation of the extract was carried out as per the guidelines given in traditional Ayurvedic textbooks. Authentic samples of the barks of FR, FM, FB and FG were collected from Arya Vaidyasala, Kottakkal, Kerala. Bark powders (100 g each) of FR, FM, FB and FG 
were mixed thoroughly and added to $6400 \mathrm{ml}$ of water, mixed well and extracted by slow boiling with constant stirring and concentrated to one-fourth of the volume. It was then filtered and lyophilized. The dry residue (NMAE), thus obtained was used for the present study. NMAE was dissolved in distilled water and administered to male albino rats.

\subsection{Chemicals and reagents}

Silymarin was purchased from Sigma Aldrich, USA (Product Code 101770964), ethanol from Changshu Yangyuan, Chemicals, China (Product code GB678-90). All the chemicals and solvents used in this study were of analytical grade.

\subsection{Experimental animals}

Animal experiments were conducted at Amala Cancer Research Centre, Amala Nagar, Thrissur, Kerala. The study was approved by the Institutional Animal Ethics Committee (Approval No. ACRC/ IAEC/2018[1]P5) and was carried out, following the guidelines of Committee for the Purpose of Control and Supervision of Experiments on Animals (CPCSEA), constituted by the Animal Welfare Division, Government of India. Male albino rats of Wistar strain weighing 200-250 g used for the study, were housed in polypropylene cages, maintained at $25 \pm 2{ }^{\circ} \mathrm{C}, 50-60 \%$ humidity and $12 \mathrm{~h}$ light and $12 \mathrm{~h}$ dark cycle. They were fed with standard pellet diet (Saidurga Foods and Feeds, Bangalore) and water $a d$ libitum.

\subsection{Experimental design}

Male albino rats weighing 200-250 g were divided into 6 groups of 6 rats each. Animals of Group 1 served as a normal group. Animals of Groups II, III, IV, V and VI were administered $20 \% \mathrm{w} / \mathrm{v}$ ethanol, $3 \mathrm{ml} / \mathrm{kg} \mathrm{b} . \mathrm{wt} /$ day, orally for 120 days. The dose of ethanol and the duration of the experiment were previously standardised (Sindhu et al., 2010). Animals of Group III were administered silymarin orally at a dose of $100 \mathrm{mg} / \mathrm{kg} \mathrm{b.wt} /$ day for 120 days (Kanaujia et al., 2011). Animals of Groups IV, V and VI were administered NMAE orally at doses 100,250 and $500 \mathrm{mg} / \mathrm{kg}$ b.wt/day, respectively for 120 days, one hour before the administration of ethanol. These doses were selected because acute toxicity studies showed that the $\mathrm{LD}_{50}$ of NMAE is greater than $5000 \mathrm{mg} / \mathrm{kg}$ b.wt. Subacute toxicity studies carried out by administering NMAE at different doses, less than $1000 \mathrm{mg} / \mathrm{kg}$ b.wt/day for 14 days also indicated that NMAE is nontoxic (unpublished data). Hence, three doses of less than $1000 \mathrm{mg} / \mathrm{kg}$ b.wt./day were administered to rats.

Body weight, food and water intake of the animals were measured periodically. After 120 days, the rats were fasted overnight and sacrificed under mild anaesthesia. Blood samples were collected from anaesthetised rats by cardiac puncture. Liver tissue was collected and weighed. Serum was separated from the blood samples by centrifugation at $3000 \mathrm{rpm}$ and used for the estimation of the various biochemical parameters.

The relative weight of the liver was calculated. Relative liver weight $=$ Liver weight $/$ Final weight of the animal $\mathrm{x} 100$.

\subsection{Biochemical assays}

The biochemical assays were carried out using ELICO SL 210 UV VIS spectrophotometer by standard protocols. Aspartate transaminase (AST) and alanine transaminase (ALT) were assayed by the method of Reitman and Frankel (1957), Alkaline phosphatase (ALP) by the method of Kind and King (1954), Gamma glutamyl transferase (GGT) by the method of Naftalin et al. (1969), bilirubin by the method of Dangerfield and Finlayson (1953), albumin by the method of Doumas and Peters (1997) and total protein by the method of Lowry et al. (1951).

Total lipids of the liver were extracted by the method of Folsch et al., (1957). Estimation of total cholesterol was carried out by method of Zlatkis et al. (1953), triglycerides by the method of Van Handel and Zilversmith (1957), and phospholipids by the method of Zilversmith and Davis (1950).

\subsection{Histopathological studies}

A portion of the liver tissue was excised and washed with normal saline. The liver tissues were fixed in $10 \%$ buffered formalin and embedded in paraffin wax. The sections were stained using haematoxylin-eosin and observed under 200X magnification in Magnus INVI microscope (Pearse, 1985).

\subsection{Statistical analysis}

Statistical analysis was carried out using one-way analysis of variance (ANOVA), followed by Tukey's post hoc multiplecomparison test in GraphPad Prism 5.0. The differences between groups were considered significant at $p$ value $<0.05$.

\section{Results}

\subsection{Weight gain, food and water intake and liver weight}

There was no change in the weight gain, food and water intake between the rats of each group. There was an increase in the relative weight of the liver in Group II (ethanol administered group) compared to the normal group whereas a significant decrease in the relative liver weight was observed in the groups treated with silymarin and NMAE when compared with Group II (Table 1).

Table 1: Effect of administration of NMAE on relative weight of liver

\begin{tabular}{|l|l|}
\hline Groups & $\begin{array}{l}\text { Relative } \\
\text { weight of liver } \\
\text { (g/100 g body } \\
\text { weight) }\end{array}$ \\
\hline Group I - Normal & $5.08 \pm 0.01$ \\
Group II - Ethanol $20 \%$ w/v ethanol $(3 \mathrm{ml} / \mathrm{kg}$ b.wt/day) & $8.23 \pm 0.99^{\mathrm{a}}$ \\
Group III Ethanol + Silymarin $(100 \mathrm{mg} / \mathrm{kg} \mathrm{b} \cdot \mathrm{wt} / \mathrm{day})$ & $6.38 \pm 0.62^{\mathrm{b}}$ \\
Group IV Ethanol + NMAE $100 \mathrm{mg} / \mathrm{kg} \mathrm{b} \cdot \mathrm{wt} / \mathrm{day}$ & $7.68 \pm 0.15^{\mathrm{b}}$ \\
Group V Ethanol + NMAE $250 \mathrm{mg} / \mathrm{kg} \mathrm{b}$.wt/day & $6.32 \pm 0.08^{\mathrm{b}}$ \\
Group VI Ethanol + NMAE $500 \mathrm{mg} / \mathrm{kg} \mathrm{b} \cdot \mathrm{wt} / \mathrm{day}$ & $5.31 \pm 0.19^{\mathrm{b}}$ \\
\hline
\end{tabular}

Values are expressed as Mean \pm SD for six animals in each group. $\mathrm{a}=p<0.05$ when compared to normal group, $\mathrm{b}=p<0.05$ when compared to ethanol administered group (Group II). 


\subsection{Effect of administration of NMAE on serum enzymes}

A significant increase in the levels of AST, ALT, ALP and GGT was observed upon administration of ethanol. The administration of NMAE at different doses reduced the levels of the toxicity marker enzymes significantly. The reduction in the levels of the enzymes at the dose of $500 \mathrm{mg} / \mathrm{kg} \mathrm{b} . \mathrm{wt} /$ day were comparable to the standard drug silymarin (Figures 1, 2 and 3).

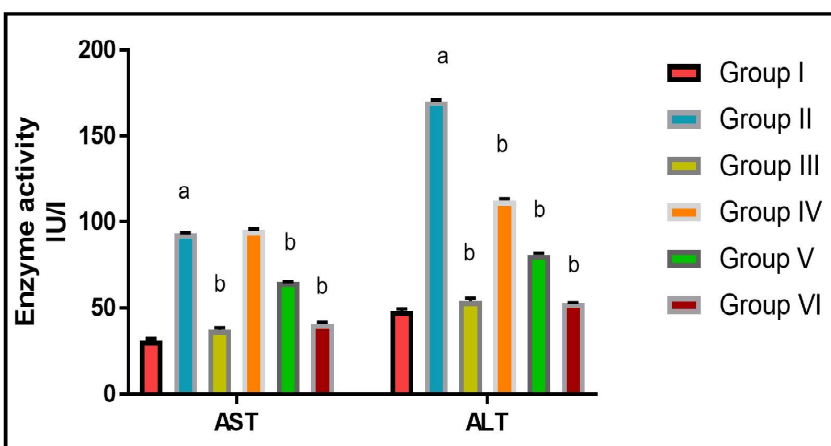

Figure 1: Effect of administration of NMAE on the activities of aspartate amino transferase and alanine aminotransferase in serum

Values are expressed as Mean \pm SD for six animals in each group. $\mathrm{a}=p<0.05$ when compared to normal group, $\mathrm{b}=p<0.05$ when compared to ethanol administered group (Group II). Group I-Normal, Group II-Ethanol (20\% w/v ethanol $3 \mathrm{ml} / \mathrm{kg}$ b.wt/day), Group III-Ethanol + Silymarin $(100 \mathrm{mg} / \mathrm{kg}$ b.wt/day), Group IV-Ethanol + NMAE (100 mg/kg b.wt/day), Group VEthanol + NMAE (250 mg/kg b.wt/day), Group VI-Ethanol + NMAE (500 mg/kg b.wt/day).

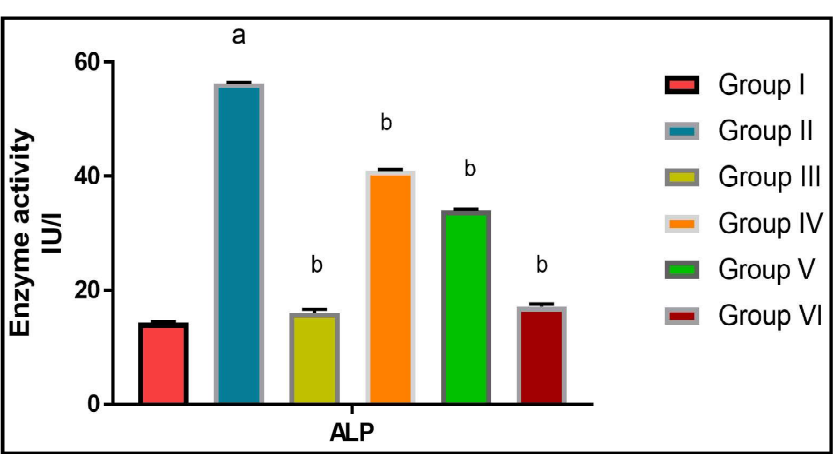

Figure 2: Effect of administration of NMAE on the activity of alkaline phosphatase in serum

Values are expressed as Mean $\pm \mathrm{SD}$ for six animals in each group. $\mathrm{a}=p<0.05$ when compared to normal group, $\mathrm{b}=p<0.05$ when compared to ethanol administered group (Group II). Group I-Normal, Group II-Ethanol (20\% w/v ethanol $3 \mathrm{ml} / \mathrm{kg}$ b.wt/day), Group III-Ethanol + Silymarin $(100 \mathrm{mg} / \mathrm{kg}$ b.wt/day), Group IV-Ethanol + NMAE (100 mg/kg b.wt/day), Group VEthanol + NMAE (250 mg/kg b.wt/day), Group VI-Ethanol + NMAE (500 mg/kg b.wt/day).

\subsection{Effect of administration of NMAE on total protein, albumin and bilirubin}

There was a significant increase in total bilirubin and marked reduction in the total protein levels upon ethanol administration. Administration of NMAE at doses of 100, 250 and $500 \mathrm{mg} / \mathrm{kg} \mathrm{b.wt} /$ day caused a significant reduction in total bilirubin and a significant increase in total protein. The serum albumin levels decreased in the ethanol treated groups. It was restored to normal upon silymarin and NMAE administration at a dose of $500 \mathrm{mg} / \mathrm{kg}$ b.wt/day. The results are shown in Figure 4 and Table 2.

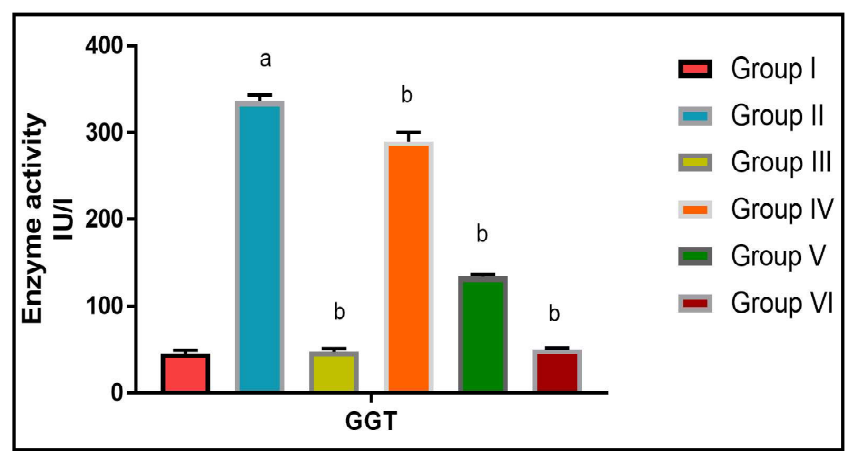

Figure 3: Effect of administration of NMAE on the activity of gamma glutamyl transferase in serum

Values are expressed as Mean $\pm \mathrm{SD}$ for six animals in each group. $\mathrm{a}=p<0.05$ when compared to normal group, $\mathrm{b}=p<0.05$ when compared to ethanol administered group (Group II). Group I-Normal, Group II-Ethanol (20\% $\mathrm{w} / \mathrm{v}$ ethanol $3 \mathrm{ml} / \mathrm{kg}$ b.wt/day), Group III-Ethanol + Silymarin $(100 \mathrm{mg} / \mathrm{kg}$ b.wt/day), Group IV-Ethanol + NMAE (100 mg/kg b.wt/day), Group VEthanol + NMAE (250 mg/kg b.wt/day), Group VI-Ethanol + NMAE (500 $\mathrm{mg} / \mathrm{kg} \mathrm{b.wt/day).}$

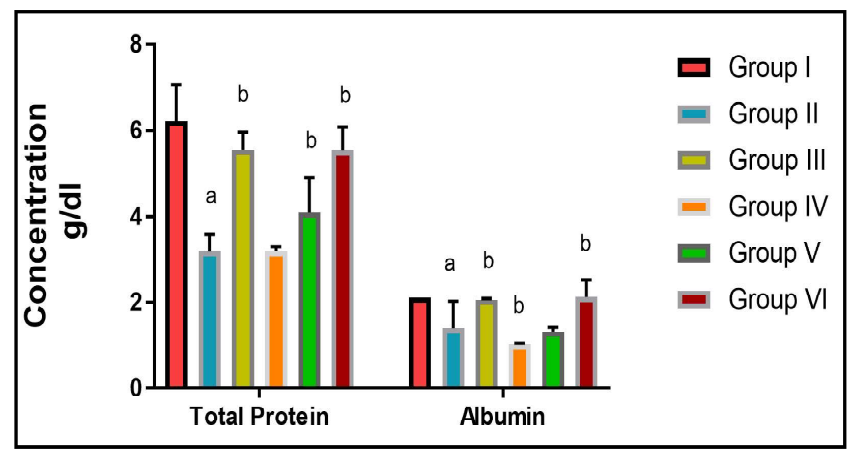

Figure 4: Effect of administration of NMAE on total protein and albumin in serum

Values are expressed as Mean \pm SD for six animals in each group. $\mathrm{a}=p<0.05$ when compared to normal group, $\mathrm{b}=p<0.05$ when compared to ethanol administered group (Group II). Group I-Normal, Group II-Ethanol $(20 \%$ $\mathrm{w} / \mathrm{v}$ ethanol $3 \mathrm{ml} / \mathrm{kg}$ b.wt/day), Group III-Ethanol + Silymarin $(100 \mathrm{mg} / \mathrm{kg}$ b.wt/day), Group IV-Ethanol + NMAE (100 mg/kg b.wt/day), Group VEthanol + NMAE (250 mg/kg b.wt/day), Group VI-Ethanol + NMAE (500 $\mathrm{mg} / \mathrm{kg}$ b.wt/day).

Table 2: Effect of administration of NMAE on total bilirubin in serum

\begin{tabular}{|l|l|}
\hline Groups & $\begin{array}{l}\text { Total bilirubin } \\
(\mathbf{m g} / \mathbf{d l})\end{array}$ \\
\hline Group I - Normal & $0.26 \pm 0.017$ \\
Group II - Ethanol $20 \%$ w/v ethanol $3 \mathrm{ml} / \mathrm{kg} \mathrm{b.wt} /$ day $)$ & $0.43 \pm 0.014^{\mathrm{a}}$ \\
Group III Ethanol + Silymarin $(100 \mathrm{mg} / \mathrm{kg} \mathrm{b.wt} /$ day $)$ & $0.25 \pm 0.01^{\mathrm{b}}$ \\
Group IVEthanol + NMAE $100 \mathrm{mg} / \mathrm{kg} \mathrm{b.wt/day}$ & $0.39 \pm 0.006^{\mathrm{b}}$ \\
Group V Ethanol + NMAE $250 \mathrm{mg} / \mathrm{kg} \mathrm{b.wt} /$ day & $0.31 \pm 0.005^{\mathrm{b}}$ \\
Group VI Ethanol + NMAE $500 \mathrm{mg} / \mathrm{kg} \mathrm{b.wt/day}$ & $0.24 \pm 0.015^{\mathrm{b}}$ \\
\hline
\end{tabular}

Values are expressed as Mean $\pm \mathrm{SD}$ for six animals in each group. $\mathrm{a}=p<0.05$ when compared to normal group, $\mathrm{b}=p<0.05$ when compared to ethanol administered group (Group II). 
3.4 Effect of administration of NMAE on cholesterol, triglycerides and phospholipids

Elevated levels of total cholesterol, triglycerides and phospholipids in serum and liver were noticed after ethanol treatment compared to the normal group. NMAE at doses of $100,250,500 \mathrm{mg} / \mathrm{kg} \mathrm{b.wt} /$ day significantly reduced the levels of cholesterol, triglycerides and phospholipids when compared to the ethanol administered group (Table 3).

Table 3: Effect of administration of NMAE on serum and liver lipids

\begin{tabular}{|c|c|c|c|c|c|c|}
\hline \multirow[t]{2}{*}{ Groups } & \multicolumn{2}{|l|}{ Cholesterol } & \multicolumn{2}{|l|}{ Triglycerides } & \multicolumn{2}{|l|}{ Phospholipids } \\
\hline & $\begin{array}{l}\text { Liver } \\
\text { (mg/g tissue) }\end{array}$ & $\begin{array}{l}\text { Serum } \\
(\mathrm{mg} / \mathrm{dl})\end{array}$ & $\begin{array}{l}\text { Liver } \\
\text { (mg/g tissue) }\end{array}$ & $\begin{array}{l}\text { Serum } \\
(\mathrm{mg} / \mathrm{dl})\end{array}$ & $\begin{array}{l}\text { Liver } \\
\text { (mg/g tissue) }\end{array}$ & $\begin{array}{l}\text { Serum } \\
(\mathrm{mg} / \mathrm{dl})\end{array}$ \\
\hline Group I - Normal & $93.48 \pm 1.58$ & $60.65 \pm 0.66$ & $128.36 \pm 1.06$ & $143.64 \pm 2.47$ & $0.1537 \pm 0.013$ & $140.51 \pm 6.14$ \\
\hline Group II - Ethanol administered & $115.93 \pm 0.20^{\mathrm{a}}$ & $83.19 \pm 1.86^{\mathrm{a}}$ & $148.56 \pm 1.56^{\mathrm{a}}$ & $160.48 \pm 2.75^{\mathrm{a}}$ & $0.2102 \pm 0.031^{\mathrm{a}}$ & $177.74 \pm 2.00^{\mathrm{a}}$ \\
\hline $\begin{array}{l}\text { Group III Ethanol + silymarin } \\
(100 \mathrm{mg} / \mathrm{kg} \text { b.wt/day) }\end{array}$ & $84.32 \pm 1.93^{b}$ & $58.81 \pm 1.26^{\mathrm{b}}$ & $125.15 \pm 0.43^{b}$ & $141.06 \pm 3.6^{b}$ & $0.1556 \pm 0.021^{\mathrm{b}}$ & $145.47 \pm 3.65^{b}$ \\
\hline $\begin{array}{l}\text { Group IV Ethanol + NMAE } \\
100 \mathrm{mg} / \mathrm{kg} \text { b.wt/day }\end{array}$ & $76.14 \pm 0.49^{b}$ & $54.21 \pm 1.0^{\mathrm{b}}$ & $149.24 \pm 3.27$ & $156.53 \pm 2.97$ & $0.1738 \pm 0.026^{\mathrm{b}}$ & $166.57 \pm 4.37^{b}$ \\
\hline $\begin{array}{l}\text { Group V Ethanol + NMAE } \\
250 \mathrm{mg} / \mathrm{kg} \mathrm{b.wt/day}\end{array}$ & $76.62 \pm 0.06^{\mathrm{b}}$ & $55.55 \pm 1.33^{\mathrm{b}}$ & $132.12 \pm 0.03^{b}$ & $139.75 \pm 2.22^{b}$ & $0.1724 \pm 0.020^{\mathrm{b}}$ & $148.36 \pm 3.56^{b}$ \\
\hline $\begin{array}{l}\text { Group VI Ethanol + NMAE } \\
500 \mathrm{mg} / \mathrm{kg} \mathrm{b.wt/day}\end{array}$ & $80.08 \pm 0.98^{\mathrm{b}}$ & $57.60 \pm 0.82^{b}$ & $101.47 \pm 0.92^{\mathrm{b}}$ & $108.30 \pm 5.95^{b}$ & $0.1615 \pm 0.024^{\mathrm{b}}$ & $135.75 \pm 2.41^{b}$ \\
\hline
\end{tabular}

Values are expressed as Mean $\pm \mathrm{SD}$ for six animals in each group. $\mathrm{a}=p<0.05$ when compared to normal group, $\mathrm{b}=p<0.05$ when compared to ethanol administered group (Group II).

\subsection{Histopathological observations}

Microscopic examination of liver tissue of the normal group stained with haematoxylin-eosin, showed normal hepatic architecture with normal sized hepatocytes, portal veins and staining pattern (Figure 5A). Marked changes in the hepatic architecture were observed in the liver tissue of rats administered ethanol (Figure 5B) and treated with standard drug silymarin (Figure 5C) and various doses of NMAE (Figures 5D, 5E and 5F), compared to the normal group. Animals administered ethanol showed signs of steatosis indicated by the presence of hepatocellular ballooning and macrovesicles. Treatment with standard drug silymarin and NMAE $(500 \mathrm{mg} / \mathrm{kg} \mathrm{b} . \mathrm{wt} /$ day) showed a significant reduction in the alterations in the hepatic architecture to an extent of $<10 \%$ macrovesicles and no ballooning, thereby demonstrating a remarkable reduction in ethanol toxicity. However, in the tissue of rats treated with low and medium doses of NMAE, a moderate to a mild level of hepatosteatosis, indicated by $<25 \%$ macrovesicles was observed (Figure 5, Table 4).

Table 4: Grading of histopathological changes of liver tissue of normal and treated rats

\begin{tabular}{|l|l|l|l|l|l|l|}
\hline Character & $\begin{array}{l}\text { Group I } \\
\text { Normal }\end{array}$ & $\begin{array}{l}\text { Group II } \\
\text { Ethanol administered }\end{array}$ & $\begin{array}{l}\text { Group III Silymarin } \\
100 \mathrm{mg} / \mathrm{kg} \text { b.wt/day }\end{array}$ & $\begin{array}{l}\text { Group IV NMAE } \\
100 \mathrm{mg} / \mathrm{kg} \text { b.wt/day }\end{array}$ & $\begin{array}{l}\text { Group V NMAE } \\
250 \mathrm{mg} / \mathrm{kg} \text { b.wt/day }\end{array}$ & $\begin{array}{l}\text { Group VI NMAE } \\
500 \mathrm{mg} / \mathrm{kg} \text { b.wt/day }\end{array}$ \\
\hline $\begin{array}{l}\text { Macrovesicles } \\
\text { Hepatocellular }\end{array}$ & 0 & 2 & 0 & 1 & 1 & 1 \\
ballooning and disarray & 0 & 1 & 0 & 1 & 0 \\
Portal tract inflammation & 0 & 2 & 0 & 0 & 0 \\
Glycogenated nuclei & 0 & 1 & 0 & 0 & 0 \\
\hline
\end{tabular}

0 - No or absence of the character; 1 - mild incidence $(<25 \%) ; 2$ - moderate incidence $(25-50 \%)$.

\section{Discussion}

In recent years, use of herbal remedies for the treatment of various ailments is increasing. Plants and plant extracts are known to play a major role in the management of liver diseases in Indian, Chinese and Korean systems of medicine. Ethnopharmacological and reverse pharmacology approach have led to the development of several leads with considerable efficacy (Patwardhan and Mashelkar, 2009). Besides single plant extracts, PHF has been used for the treatment of liver dysfunction over the years. Some of them are available in the market under different trade names (Girish and Pradhan, 2012; Dhiman and Chawla, 2005). Ghosh et al. (2011) have also listed some of the available PHF effective for the treatment of liver diseases.
However, only very few PHF used in traditional medicine have been evaluated scientifically for their therapeutic efficacy and safety.

Alcohol consumption has become a major challenging socioeconomic and medical problem in recent years. Excessive consumption of ethanol is one of the causes of cardiovascular, hepatic, pancreatitic and nephrotic disorders. Being the primary site of ethanol metabolism, injury caused to the liver is enormous. Steatosis occurs in the initial stages, followed by oxidative stress and inflammation which may progress to fibrosis and necrosis (Osna et al., 2017; Becker et al., 1996; Crabb, 1999; Ponnappa and Rubin, 2000; Altamirano and Bataller, 2011). 


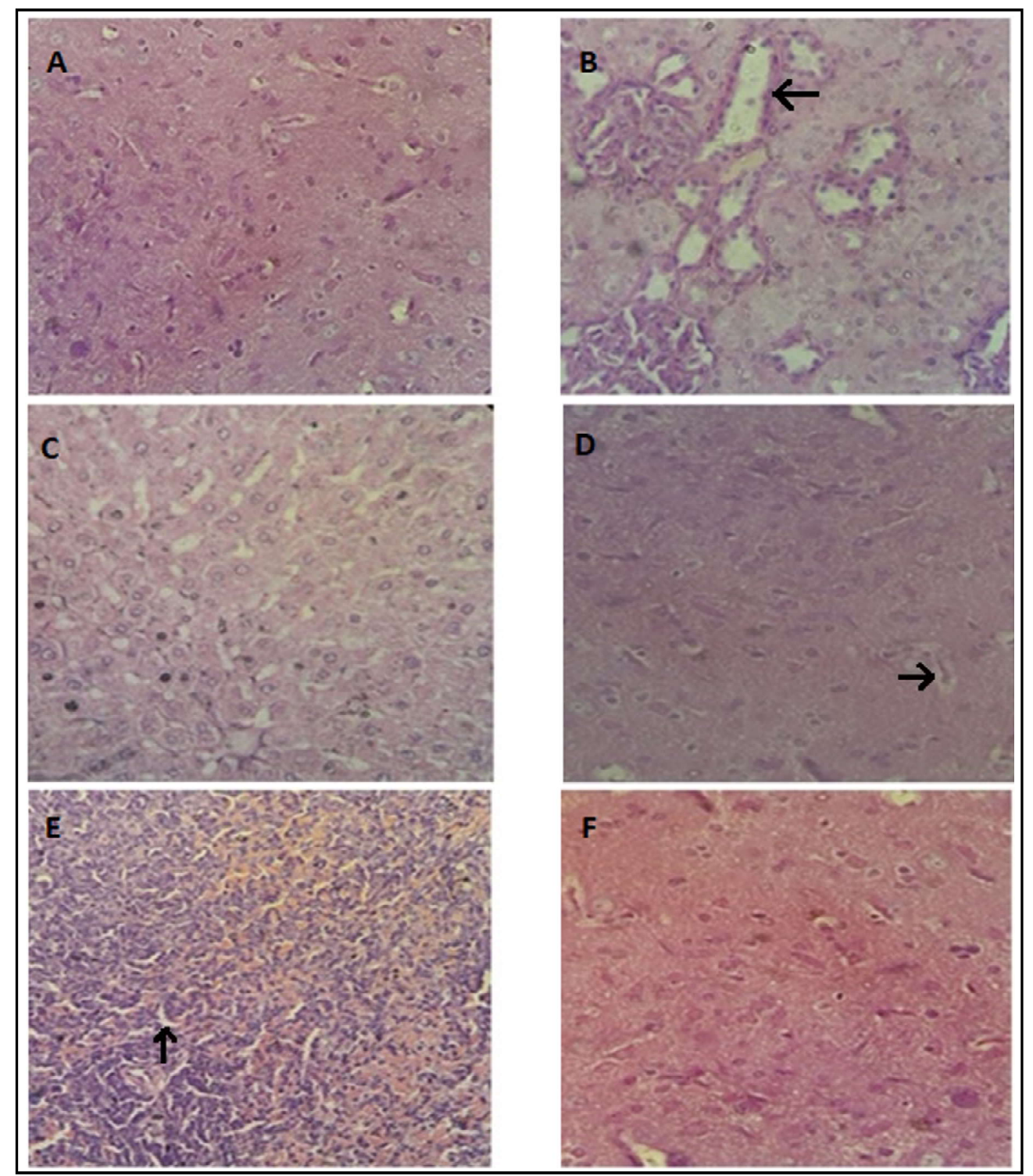

Figure 5: Histopathological changes of liver tissue of normal and NMAE treated rats Photomicrograph of liver tissue stained with haematoxylin-eosin observed under 200X magnification. Normal group (A) showed normal hepatic architecture. Ethanol administration caused fatty changes and ballooning (B) (Indicated by arrows). Treatment with standard drug silymarin (C) and NMAE (500 mg/kg b.wt/day) (F), showed a significant reduction in the alterations of the hepatic architecture induced by ethanol. In the liver tissue of rats treated with NMAE at $100 \mathrm{mg} / \mathrm{kg}$ b.wt/day and $250 \mathrm{mg} / \mathrm{kg}$ b.wt/day (D and E) a moderate to mild level of hepatosteatosis was observed.

In the present study, the hepatoprotective activity of NMAE has been investigated on ethanol induced hepatotoxicity in male albino rats. The aqueous extract was used in the present study.

In this study, the activities of the enzymes, AST, ALT and ALP which are considered to be the most sensitive biochemical markers of liver injury increased in the ethanol treated group. These enzymes are found in the cytoplasm of hepatocytes and damage of the cells leads to their rapid leakage into the blood circulation. Hence, elevated levels are observed in serum during hepatic damage. Elevated levels of GGT are observed in chronic alcoholism, pancreatic, renal, pulmonary diseases and diabetes (Vasudevan and Sreekumari, 2007). The significant increase in the levels of these marker enzymes in ethanol treated groups indicates hepatic damage. The significant reduction in the levels of AST, ALT, ALP and GGT in the serum when treated with silymarin and NMAE at different doses may be due to their decreased leakage from the hepatocytes and hence, indicates protective effect.

Bilirubin formed by the catabolism of heme is excreted as glucuronide through the bile. During hepatic damage, elevated levels of bilirubin are noticed in the serum. In the current study, bilirubin 
level was found to be increased in the ethanol treated rats. The elevated levels of bilirubin decreased in NMAE treated groups in a dose dependant manner. In the groups administered NMAE at 500 $\mathrm{mg} / \mathrm{kg}$ b.wt/day and silymarin, bilirubin levels were decreased to the normal value.

The decrease in the levels of total protein and albumin in the ethanol treated rats suggests that the protein synthetic machinery of the liver may be deranged by the oxidative stress induced by ethanol (Topf et al., 2019). The albumin levels were restored to normal in the rats treated with NMAE at a dose of $500 \mathrm{mg} / \mathrm{kg} \mathrm{b.wt} /$ day.

In the present study, the relative liver weight in ethanol treated rats was more than that of the normal group. This may be due to the deposition of fat and the inflation of hepatocytes. The liver weights were significantly lowered in NMAE treated groups. The hyperlipidaemia induced by ethanol was restored to normal after the administration of NMAE and silymarin. Increased hepatic and serum lipids upon ethanol administration may be due to an increase in lipogenesis, decreased lipophagy and oxidation and variations in the levels of lipid transport proteins (Osna et al., 2017; Maras et al., 2019). The decrease in the levels of lipids in silymarin and NMAE administered rats may be due to their action on the enzymes involved in lipogenesis or transport. Histopathological observations also indicated a reduction of steatosis and ethanol toxicity.

Similar results on the hepatoprotective activity of plant extracts have been reported by other workers also (Kim et al., 2020; Nanotkar et al., 2016; Kushwaha et al., 2017; Dikshit et al., 2016; Nirmala et al., 2012). Khan et al (2018) have reported the hepatoprotective effect and phytochemical analysis of a PHF in $\mathrm{CCl}_{4}$ induced hepatotoxicity in rats. The hepatoprotective activity of the plant extracts may be due to the polyphenols, alkaloids and flavonoids present in them (Mondal et al., 2017; El hawary et al., 2018; Bakr et al., 2018). Further studies to identify the phytochemicals of NMAE by metabolomic profiling and studies at the molecular level to reveal the mechanism of hepatoprotective action of NMAE are in progress.

\section{Conclusion}

The PHF NMAE mitigates the toxic effect of ethanol in the rat model. The activities of the toxicity marker enzymes ALP, AST, ALT and GGT and serum bilirubin reduced in NMAE treated rats compared to the ethanol administered group. The decrease in the levels of total protein and albumin on ethanol administration was restored to normal upon treatment with NMAE at a dose of 500 $\mathrm{mg} / \mathrm{kg} \mathrm{b}$.wt/day. Histopathological studies also indicated the attenuation of ethanol toxicity. The effect of NMAE at $500 \mathrm{mg} / \mathrm{kg}$ b.wt/day was comparable to that of the standard drug silymarin.

\section{Acknowledgements}

We acknowledge the financial support to the Postgraduate and Research Department of Microbiology from Kerala State Council for Science Technology and Environment, Thiruvananthapuram, in the SARD scheme and Department of Science and Technology, New Delhi, Government of India in the FIST scheme.

\section{Conflict of interest}

The authors declare that there are no conflicts of interest in the course of conducting the research. All the authors had final decision regarding the manuscript and decision to submit the findings for publication.

\section{References}

Ahsan, M.R.; Islam, K. M.; Bulbul, I. J.; Musaddik, M. A. and Haque, E. (2009). Hepatoprotective activity of methanol extract of some medicinal plants against carbon tetrachloride-induced hepatotoxicity in rats. Eur. J. Sci. Res., 37(2):302-310.

Altamirano, J. and Bataller, R. (2011). Alcoholic liver disease: Pathogenesis and new targets for therapy. Nat. Rev. Gastroenterol. Hepatol., 8(9):491-501.

Bakr, R. O.; Fayeed, M. A. A.; Fayez, A. M.; Gabr, S. K.; El Fishawy, A. M. and El Aily, T. S. (2018). Hepatoprotective activity of Erythrina neillii leaf extract and characterization of its phytoconstituents, Phytomed., 53:9-17.

Becker, U.; Deis, A.; Sorensen, T. I.; Gronbaek, M.; Borch Johnsen, K.; Muller, C. F.; Schnohr, P. and Jensen, G. (1996). Prediction of risk of liver disease by alcohol intake, sex, and age: A prospective population study. Hepatology, 23(5):1025-1029.

Channabasavaraj, K.P.; Badami, S. and Bhojraj S. (2008). Hepatoprotective and antioxidant activity of methanol extract of Ficus glomerata. J. Natural Med., 62(3):379-383.

Chattopadhyay, R. (2003). Possible mechanism of hepatoprotective activity of Azadirachta indica leaf extract: Part II. J. Ethnopharmacol., 89(2-3):217-219.

Chopra, R. N.; Chopra, I. C. and Varma, B. S. (1992). Supplement to glossary of indian medicinal plants, CSIR, New Delhi, India. pp:29-30.

Crabb, D. W. (1999). Pathogenesis of alcoholic liver disease: Newer mechanisms of injury. Keio. J. Med., 48(4):184-188.

Dangerfield, W. G. and Finlayson R. (1953). Estimation of bilirubin in serum. J. Clin. Path., 6(3):173-177.

Daniyal, M.; Akram, M.; Zainab, R.; Munir, N.; Sharif, A.; Shah, S.M.; Liu, B. and Wang, W. (2019). Prevalence and current therapy in chronic liver disorders. Inflammopharmacology, 27(2):213-231.

Dhiman, R. K. and Chawla, Y. K. (2005). Herbal medicines for liver diseases. Dig. Dis. Sci., 50(10):1807-1812.

Dikshit, P.; Tyagi, M. K.; Shukla, K.; Sharma, S.; Gambhir, J. K. and Shukla, R. (2016). Hepatoprotective effect of stem of Musa sapientum Linn in rats intoxicated with carbon tetrachloride. Ann. of Hepatol., 10(3):333-339.

Doumas, B.T. and Peters Jr, T. (1997). Serum and urine albumin: A progress report on their measurement and clinical significance. Clin. Chim. Acta, 258(1):3-20.

El-hawary, S. S.; Ali, Z. Y. and Younis, I. Y. (2018). Hepatoprotective potential of standardized Ficus species in intrahepatic cholestasis rat model: Involvement of nuclear factor- $\kappa \mathrm{B}$, and farnesoid X. Receptor signaling pathways. J. Ethnopharmacol., https://doi.org/10.1016/ j.jep.2018.11.026

Folch, J., Lees, M. and Stanley, G.S. (1957). A simple method for the isolation and purification of total lipids from animal tissues. J. Biol. Chem., 226(1):497-509. 
Ghosh, N.; Ghosh, R.; Mandal, V. and Mandal, S.C. (2011). Recent advances in herbal medicine for treatment of liver diseases. Pharm. Biol. 49(9):970-988.

Girish, C. and Pradhan, S.C. (2012). Indian herbal medicines in the treatment of liver diseases: Problems and promises. Fundam. Clin. Pharmacol., 26(2):180-189.

Gurav, A.; Nabi, S.; Vijayakumar, H. and Mondal, D. B., (2017). Evaluation of hepatoprotective and antidiarrhoeal activity of guduchi, Tinospora cordifolia (Willd.) Miers ex Hook. f. and Thoms. in experimental rats. Ann. Phytomed., 6(2):156-161.

Kanaujia, V. K.; Irchhaiya, R.; Singh, H. K.; Kailasiya, D.; Verma, M.; Yadav, R. D. and Shivhare, D. (2011). Evaluation of hepatoprotective activity on the leaves of Ficus benjamina Linn. J. Nat. Prod. Plant Resour., 1(3):59-69.

Khan, F. S.; Akram, M.; Aslam, N.; Zaheer, J.; Bint, S.; Shah, S. M.; Tahir, I. M. and Sharif, A. (2018). Phytochemical analysis and hepatoprotective effect of polyherbal formulation on $\mathrm{CCl} 4$ induced hepatotoxicity in mice. Pak. J. Pharm. Sci., 31(6):2719-2723.

Kim, T.M.; Kim, K.H.; Jo, J.H.; Park, J.; Kwon, Y.S. and Yang, J.H. (2020) Hepatoprotective effect of a novel lactic acid fermented garlic extract functional food product against acute liver injury. Food Sci. Nutr., 8(2):1012-1019.

Kind, P. R. N. and King, E. (1954). Estimation of plasma phosphatase by determination of hydrolysed phenol with amino-antipyrine. J. Clin. Pathol., 7(4):322-326.

Kumar, A. N. and Pari, L. (2003). Antioxidant action of Moringa oleifera Lam. (drumstick) against antitubercular drugs induced lipid peroxidation in rats. J. Med. Food, 6(3):255-259.

Kushwaha, N.; Mondal, D. B. and Singh, K. P. (2017). Comparative evaluation of hepatoprotective efficacy of Terminalia chebula Retz. and Terminalia belerica (Gaertn.) Roxb. fruits extracts in rat model. Ann. Phytomed., 6(2):149-155.

Lowry, O.H.; Rosebrough, N.J.; Farr, A.I. and Randall, R.J. (1951). Protein measurement with folin phenol reagent. J. Biol. Chem., 193(1): 265-275.

Mandal, S.C.; Maity, T.K.; Das, J.; Pal, M. and Saha, B.P. (1999). Hepatoprotective activity of Ficus racemosa leaf extract on liver damage caused by carbon tetrachloride in rats. Phytother. Res., 13(5):430-432.

Maras, J.S.; Das. S.; Bhat. A.; Kumar, Vyas, A.; Yadav, G.; Chaudhary, S.; Sukriti, S.; Gupta, A.C.; Bihari, C.; Mahiwall, R. and Sarin, S.K. (2019). Dysregulated lipid transport proteins correlate with pathogenesis and outcome in severe alcoholic hepatitis. Hepatol. Commun., 3(12):1598-1625.

Mondal, S.; Ghosh, D.; Ganapaty, S.; Chekuboyina, S. V. G. and Samal, M. (2017) Hepatoprotective activity of macrothelypteris torresiana (Gaudich.) aerial parts against CCl4-induced hepatotoxicity in rodents and analysis of polyphenolic compounds by HPTLC. J. Pharm. Analysis, 7:181-189.
Naftalin, L.; Sexton, M.; Whitaker, J.F. and Tracey, D. (1969). A routine procedure for estimating serum $\gamma$-glutamyl-transpeptidase activity. Clin. Chim. Acta., 26(2):293-296.

Nanotkar, R. Y.; Jangde, C.R.; Jagtap, D.G. and Sar, T.K. (2016). Effect of Careya arborea Roxb.on CCl4 induced liver damage in rats. Ann. Phytomed., 5(2):113-117.

Nirmala, M.; Girija, K.; Lakshman, K. and Divya T. (2012). Hepatoprotective activity of Musa paradisiaca on experimental animal models. Asian Pac. J. of Trop. Biomed., 2(1):11-15.

Osna, N.A.; Donohue Jr, T.M. and Kharbanda K. K. (2017). Alcoholic liver disease: Pathogenesis and current management. Alcohol Res.: Current Reviews, 38(2):147-161.

Parasuraman, S.; Thing, G.S. and Dhanaraj, S.A. (2014). Polyherbal formulation: Concept of Ayurveda. Pharmacogn. Rev., 8(16):73.

Patwardhan, B. and Mashelkar, R.A. (2009). Traditional medicine-inspired approaches to drug discovery: Can Ayurveda show the way forward? Drug Discovery Today, 14:(15-16):804-811.

Pearse, A.G.E. (1985). Histochemistry: Theoretical and applied Vol 2, Fourth edition, Churchill Livingstone, Edinburgh. pp:632-635.

Ponnappa, B.C. and Rubin, E. (2000). Modeling alcohol's effects on organs in animal models. Alcohol Res. Health, 24(2):93-104.

Reitman, S. and Frankel, S. (1957). A colourimetric method for the determination of serum glutamic oxaloacetic and glutamic pyruvic transaminases. Am. J. Clin. Path. 28(1):56-63.

Sindhu, E. R.; Firdous, A. P.; Preethi, K. C. and Kuttan, R. (2010). Carotenoid lutein protects rats from Paracetamol, $\mathrm{CCl}_{4}$ and Ethanol induced liver damage. J. Pharm. and Pharmacol., 62(8):1054-1060.

Topf, U.; Uszczynska-Ratajczak, B. and Chacinska, A. (2019). Mitochondrial stress-dependent regulation of cellular protein synthesis. J. Cell Sci., 132(8):jcs226258.

Uzun, H.; Simsek, G.; Aydin, S.; Unal, E.; Karter, Y.; Yelmen, K. N.; Vehid, S.; Curgunlu, A. and Kaya, S. (2005). Potential effects of L-NAME on alcohol-induced oxidative stress. World J. Gastroenterol., 11(4):600-604.

Van Handel, E. and Zilversmith, D.B. (1957). Micro method for direct determination of serum triglycerides. J. Lab. Clin. Med., 50(1):152-157.

Vasudevan, D.M. and Sreekumari, S. (2007). Textbook of Biochemistry for medical students, Fifth edition, Jaypee New Delhi, India. pp:491497.

Warrier, P.K.; Nambiar, V.P.K. and Ramankutty, C. (1995). Indian medicinal plants: A compendium of 500 species, vol. 3. Orient Longman Ltd., Chennai, India. pp:120-123.

Zilversmit, D.B. and Davis, A.K. (1950). Microdetermination of plasma phospholipids by trichloroacetic acid precipitation. J. Lab. Clin. Med., 35(1): 155-160.

Zlatkis, A.; Zak, B. and Boyle, A.J. (1953). A new method for the direct determination of serum cholesterol. J. Lab. Clin. Med., 41(3):486492 .

Citation S. Jyothilekshmi; A. K. Valsa and Ramadasan Kuttan (2020). Protective effect of the polyherbal formulation, Nalpamaram against ethanol induced hepatotoxicity in rats. Ann. Phytomed., 9(2):232-238. http://dx.doi.org/10.21276/ ap.2020.9.2.21 